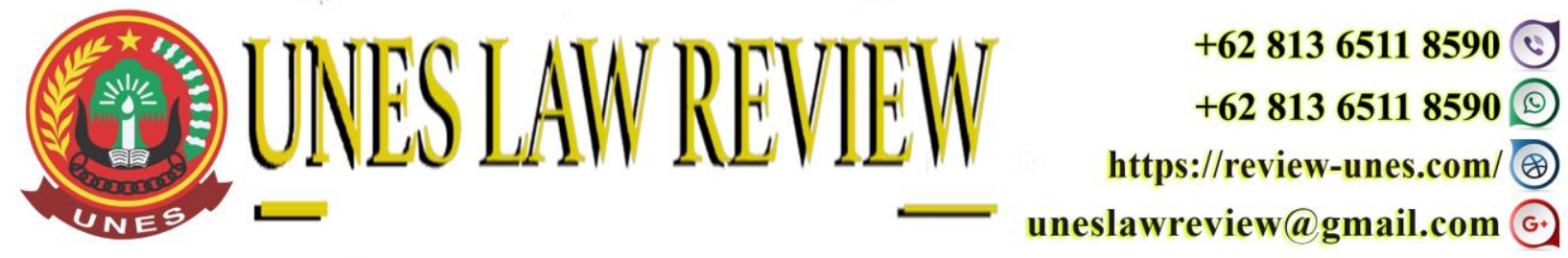

DOI: https://doi.org/10.31933/unesrev.v4i1 Diterima: 01/10/2021, Diperbaiki: 10/10/2021, Diterbitkan: 27/10/2021

\title{
PERTIMBANGAN HAKIM DALAM MENJATUHKAN PUTUSAN TERHADAP TERDAKWA TINDAK PIDANA PENGHINAAN BERDASARKAN UNDANG-UNDANG INFORMASI DAN TRANSAKSI ELEKTRONIK \\ (Analisis Putusan Nomor 218/Pid.Sus/2020/PN.Pdg dan Putusan Nomor 356/Pid.Sus/2020/PN.Pdg)
}

\section{Wami Irma Suryani}

Program Magister Ilmu Hukum, Universitas Ekasakti, Padang, Indonesia.

Email: wamiirmasuryani@gmail.com

Corresponding Author: Wami Irma Suryani

\section{ABSTRACT}

The provisions of Article 27 paragraph (3) of Law Number 19 of 2016 concerning Amendments to Law Number 11 of 2008 concerning Electronic Information and Transactions specifically regulates defamation or insults carried out by utilizing information technology through electronic media. Dissemination of electronic information containing pornographic content, fake news, defamation, insults is a type of criminal act that is actually the most prevalent in society. The Padang District Court on decision number: 218/Pid.Sus/2020/PN.Pdg and decision number: 356/Pid.Sus/2020/PN.Pdg handed down a different verdict against the defendant in the criminal act of humiliation.

Keywords: Judge, Decision, Criminal Act, ITE

\section{ABSTRAK}

Ketentuan Pasal 27 ayat (3) Undang-Undang Nomor 19 Tahun 2016 tentang Perubahan Atas Undang-Undang Nomor 11 Tahun 2008 tentang Informasi dan Transasksi Elektronik secara khusus mengatur mengenai pencemaran nama baik atau penghinaan yang dilakukan dengan memanfaatkan teknologi informasi melalui media elektronik. Penyebaran informasi elektronik yang mengandung konten pornografi, berita bohong, pencemaran nama baik, penghinaan adalah jenis perbuatan pidana yang sesungguhnya paling marak terjadi ditengah-tengah masyarakat. Pengadilan Negeri Padang pada putusan nomor : 218/Pid.Sus/2020/PN.Pdg dan putusan nomor : 356/Pid.Sus/2020/PN.Pdg menjatuhkan putusan yang berbeda terhadap terdakwa dalam tindak pidana penghinaan.

Kata Kunci: Hakim, Putusan, Tindak Pidana, ITE 


\section{PENDAHULUAN}

Penggunaan dan pemanfaatan teknologi informasi harus terus dikembangkan untuk menjaga, memelihara, dan memperkukuh persatuan dan kesatuan nasional berdasarkan peraturan perundang-undangan demi kepentingan nasional. Selain itu, bermacam manfaat teknologi informasi berperan penting dalam perdagangan dan pertumbuhan perekonomian nasional guna mewujudkan kesejahteraan masyarakat. ${ }^{1}$

Perkembangan teknologi informasi mengakibatkan dunia menjadi tanpa batas dan menyebabkan perubahan sosial yang secara signifikan berlangsung dengan cepat. Kejahatan yang terjadi seiring dengan terjadinya perkembangan teknologi informasi dan internet disebut dengan cyber crime. Cyber crime atau disebut juga kejahatan dalam internet ini mengancam siapapun dengan resiko tertangkap yang sangat minim oleh individu maupun kelompok sehingga menimbulkan kerugian yang sangat besar sebagai dampak bagi masyarakat maupun negara. ${ }^{2}$

Perbuatan melawan hukum di dunia maya merupakan fenomena yang sangat mengkhawatirkan, mengingat tindakan carding, hacking, penipuan, terorisme dan penyebaran informasi destruktif telah menjadi bagian dari aktivitas pelaku kejahatan dunia maya. Kenyataan itu sangat kontras dengan ketiadaan regulasi yang mengatur pemanfaatan teknologi informasi dan komunikasi diberbagai sektor. Oleh karena itu, untuk menjamin kepastian hukum, pemerintah berkewajiban melakukan regulasi terhadap berbagai aktivitas terkait dengan pemanfaatan teknologi informasi dan komunikasi. ${ }^{3}$

Media sosial adalah sebuah media online dimana para pengguna dapat dengan mudah beradaptasi, berbagi, dan menciptakan isi. Media social sangat beragam, sehingga masyarakat dapat mengakses dengan mudah dan memanfaatkan untuk interaksi sosial. Saat ini media sosial yang sering digunakan masyarakat seperti instagram, facebook, whatsapp yang sejatinya digunakan sebagai penghubung dan tempat untuk mamberikan informasi dan hal-hal positif sering sekali disalahgunakan untuk menghujat dan membicarakan hal yang tidak semestinya diketahui oleh orang banyak. ${ }^{4}$

Undang-Undang Nomor 19 Tahun 2016 tentang Perubahan Atas Undang-Undang 11 Tahun 2008 tentang Informasi dan Transaksi Elektronik (UU ITE Perubahan) adalah wujud dari tanggung jawab yang harus diemban oleh negara untuk memberikan perlindungan maksimal kepada seluruh aktivitas pemanfaatan teknologi informasi dan komunikasi di dalam negeri agar terlindungi dengan baik dari potensi kejahatan dan penyalahgunaan teknologi. Dalam memeriksa serta memutus perkara pidana yang ada dihadapannya, hakim memiliki kebebasan untuk melakukan penilaian. ${ }^{5}$

\footnotetext{
${ }^{1}$ Danrivanto Budhijanto, Revolusi Cyber Law Indonesia, Refika Aditama, Jakarta, 2017, hlm 5

${ }^{2}$ Mardani, Bunga Rampai Hukum Aktual, Ghalia Indonesia, Jakarta, 2009, hlm. 91

${ }^{3}$ Siswanto Sunarso, Hukum Informasi dan Transaksi Elektronik, Rineka Cipta, Jakarta, 2009, hlm. 40

${ }^{4} \mathrm{http}$;//www.romelteamedia.com/media sosial pengertian dan karateristik, 2018. Html Diakses pada tanggal 2 November 2020 pukul $12.30 \mathrm{WIB}$

${ }^{5}$ Fahmiron, Pertimbangan Hakim Dalam Perampasan Aset Koruptor (Dalam Perspektif Perlindungan Hak Anak), Rajawali Pers, Depok, 2017, hlm. 15
} 
Perkara penghinaan yang dilakukan melalui media elektronik seperti yang terdapat pada Putusan Nomor 218/Pid.Sus/2020/PN.Pdg, yang melibatkan Ketua Asosiasi Kapal Selancar Sumatera Barat (AKSSB) dengan anggota AKSSB lainnya. Ketua AKSSB yang bernama $\mathrm{H}$. Zainul Rahim Zein, S.H mengirimkan sebuah pesan di grup whatsapp yang dianggap sebagai sebuah penghinaan oleh anggota lain yang bernama Rudi Khelces. Akibat dari pesan tersebut rudi Khelces melaporkan ketua dar AKSSB ini kepada pihak yang berwajib atas penghinaan atau pencemaran nama baik.

Selanjutnya"Putusan Nomor 356/Pid.Sus/2020/PN.Pdg, telah melibatkan seorang bernama Gonzales yang mengirimkan SMS kepada Ilham Sastrawan dan Dedi Muhammad Siddiq yang dalam perkara ini sebagai saksi. Dalam SMS tersebut terdakwa menyatakan bahwa istri dari Rosmawi yang dalam hal ini sebagai pelapor sedang melakukan zina dengan seseorang. Akibatnya Rosmawi tidak terima dan melaporkan hal tersebut jepada pidah yang berwajib.

Berdasarkan kedua putusan tersebut hakim menjatuhkan putusan yang berbeda yakni pada Putusan Nomor 218/Pid.Sus/2020/PN.Pdg terdakwa dinyatakan tidak bersalah oleh hakim dan dijatuhkan putusan bebas oleh hakim sedangkan pada"Putusan Nomor 356/Pid.Sus/202/PN.Pdg hakim menjatuhkan pidana penjara selama 8 bulan.

Berdasarkan permasalahan yang telah diuraikan diatas, maka penulis tertarik untuk lebih mengetahui lebih lanjut tentang pertimbangan hakim dalam menjatuhkan putusan terhadap terdakwa tindak pidana penghinaan berdasarkan UU ITE sehingga dalam penelitian ini penulis akan membahasa dengan permasalahan yaitu bagaimana pertimbangan hakim dalam menjatuhkan putusan terhadap terdakwa tindak pindana berdasarkan UU ITE pada Putusan Nomor: 218/Pid.Sus/2020/PN.Pdg dan Putusan Nomor: 356/Pid.Sus/2020/PN.Pdg.

\section{METODE PENELITIAN}

Metode penelitian yang digunakan dalam penelitian ini adalah sebagai berikut:

1. Spesifikasi Penelitian

Penelitian ini adalah penelitian yang bersifat yaitu penelitian yang menggambarkan tentang pertimbangan hakim dalam menjatuhkan putusan terhadap terdakwa tindak pidana informasi dan transaksi elektronik yang mengandung unsur penghinaan pada putusan Nomor 218/Pid.Sus/2020/Pn.Pdg dan Putusan Nomor 356/Pid.Sus/2020/ Pn.Pdg.

2. Metode Pendekatan

Pendekatan yang-digunakan pada penelitian ini adalalah pendekatan yuridis normatif, yaitu dengan melakukan penelitian hukum secara in concreto mengenai Putusan Nomor 218/Pid.Sus/2020/Pn.Pdg dan Putusan Nomor 356/Pid.Sus/2020/Pn.Pdg.

\section{HASIL DAN PEMBAHASAN}

Pertimbangan Hakim Dalam Menjatuhkan Putusan Terhadap Terdakwa Tindak Pidana Penghinaan Berdasarkan Undang-Undang Informasi Dan Transaksi Elektronik

\section{Putusan Nomor : 218/Pid.Sus/2020/PN.Pdg} Pertimbangan Yuridis 
Pertimbangan yang bersifat yuridis adalah pertimbangan hakim yang didasarkan pada faktor-faktor yang terungkap dalam persidangan dan oleh undang-undang telah ditetapkan sebagai hal yang harus diamati dalam putusan. Antara lain yakni dakwaan jaksa penuntut umum, keterangan terdakwa dan saksi, barang bukti, pasal-pasal didalam peraturan hukum pidana dan lain sebagainya.

a) Berdasarkan dakwaan jaksa penuntut umum dalam kasus ini maka terdakwa dihadapkan ke persidangan dengan dakwaan kumulatif yakni didakwakan beberapa tindak pidana sekaligus dan semua dakwaan harus dibuktikan satu persatu. Dakwaan yang tidak terbukti harus dinyatakan secara tegas dan dituntut pembebasan dari dakwaan tersebut. Dakwaan ini digunakan dalam hal terdakwa melakukan beberapa tindak pidana yang masing-masing merupakan tindak pidana yang berdiri sendiri.

Terdakwa didakwa oleh Penuntutu Umum sebagai berikut :

\section{Kesatu ;}

Perbuatan terdakwa sebagaimana diatur dan diancam pidana dalam Pasal 45 ayat (3) juncto Pasal 27 ayat (3) UU ITE Perubahan.

Kedua;

Perbuatan melanggar ketentuan sebagaimana diatur dalam Pasal 310 ayat (2) KUHP.

\section{Ketiga;}

Oleh karena dakwaan alternatif kedua tidak terbukti, Majelis Hakim mempertimbangkan dakwaan alternatif ketiga yaitu Pasal 311 ayat (1) yang mana untuk membuktikan unsur-unsur dari pasal ini maka juga masuk di dalamnya unsur-unsur dari Pasal 310 KUHP.

b) Berdasarkan keterangan terdakwa

c) Berdasarkan keterangan saksi

Untuk membuktikan dakwaan Penuntut Umum menghadirkan saksi-saksi yang terdiri atas nama Rudi Khelces, Edi Solihin, Hariyo Seto, Lyrianti Dakhi, Hendra Tjugito. Atas keterangan saksi tersebut, terdakwa membenarkan dan tidak membantah.

\section{Pertimbangan Non Yuridis}

Pertimbangan non yuridis meliputi antara lain :

a) Pertimbangan berdasarkan hal yang memberatkan terdakwa;

b) Pertimbangan berdasarkan hal yang merigankan terdakwa.

Dalam kasus ini tidak ditemukan hal-hal yang memberatkan dan meringankan terdakwa disebabkan karena putusan bebas terhadap perkara ini. Sehingga hakim di dalam memutus perkara bebas dalam tindak pidana pencemaran nama baik memperoleh fakta hukum sebagai berikut :

a) Bahwa Terdakwa adalah Ketua dan juga anggota dari Asosiasi Kapal Selancar Sumatera Barat (AKSSB) dari sejak berdirinya yaitu tanggal 23 September 2008 sampai dengan sekarang;

b) Bahwa anggota AKSSB itu terdiri dari para pemilik dan pengurus kapal selancar pariwisata di Sumatera Barat; 
c) Bahwa AKSSB mempunyai grup Whatsapp (WAG) dimana Terdakwa menggunakan nomor telepon seluler (HP) dengan nomor simcard 62811669988 dan pada akun What'sApp terdakwa menggunakan nama (username) AIM ZEIN dan Terdakwa adalah admin dari WAG AKSSB;

d) Bahwa Anggota WAG AKSSB berjumlah 18 (delapan belas) orang dan mayoritas merupakan WNA sehingga komunikasi didalam group lebih banyak menggunakan Bahasa Inggris;

e) Bahwa diantara anggota WAG AKSSB adalah saksi EDI SOLIHIN, saksi LYRIANTI DAKHI, saksi HENDRA TJUGITO dan DAVE THOMAS sedangkan saksi RUDI KHELCES bukan anggota WAG AKSSB; $p$

f) Bahwa pada pertengahan bulan Maret 2018 saksi EDI SOLIHIN yang adalah anggota WAG AKSSB diajak oleh teman saksi yang bernama Firdaus ke Kantor Imigrasi Padang untuk diperkenalkan dengan pegawai Kantor Imigrasi yang bernama saksi HARIYO SETO yangmana pada waktu bertemu tersebut Saksi HARIYO SETO ada bertanya kepada saksi EDI SOLIHIN apakah saksi merupakan anggota AKSSB serta masuk ke dalam WAG AKSSB dan saksi EDI SOLIHIN mengatakan kalau ia masuk anggota WAG AKSSB;

g) Bahwa saksi Hariyo Seto sebelumnya pernah ada permasalahan dengan anggota WAG AKSSB yaitu dengan David Peter Thomas yang telah melaporkan saksi Hariyo Seto tentang Pungli ke Kemenkumham;

h) Bahwa Saksi HARIYO SETO kemudian meminta izin kepada saksi EDI SOLIHIN untuk melihat-lihat dan membaca percakapan dalam WAG AKSSB dan saksi EDI SOLIHIN mengizinkannya dengan menyerahkan HPnya kepada Saksi HARIYO SETO ;

i) Bahwa setelah saksi EDI SOLIHIN pulang tidak lama kemudian datang Saksi RUDI KHELCES ke kantor Imigrasi menemui saksi HARIYO SETO dan di dalam pertemuan antara RUDI KHELCES dengan HARIYO SETO tersebut HARIYO SETO memberitahukan kepada RUDI KHELCES kalau HARIYO SETO telah melihat hand phone (HP) milik saksi EDI SOLIHIN yang adalah anggota WAG AKSSB yangmana isi dari WAG AKSSB tersebut ada menjelekjelekan RUDI KHELCES;

j) Bahwa atas pemberitahuan saksi HARIYO SETO tersebut kemudian bertemulah ketiga orang saksi yaitu HARIYO SETO, RUDI KHELCES dan EDI SOLIHIN di Warung Mie Aceh di daerah by Pass Padang yangmana kemudian saksi Rudi Khelces meminta izin kepada Saksi Edi Solihin untuk membaca percakapan WAG AKSSB di HP Saksi Edi Solihin dan Saksi Edi Solihin mengizinkannya dengan menyerahkan Hpnya kepada saksi Rudi Khelces;

k) Bahwa setelah membaca percakapan WAG AKSSB di HP Saksi EDI SOLIHIN lalu saksi Rudi Khelces men-screenshot percakapan tersebut lalu mengirimkan hasil screenshot nya ke HP saksi Rudi Khelces sendiri serta ke e-mail -nya lalu 
saksi Rudi Khelces juga menyalinnya ke dalam sebuah flashdisk kemudian mencetaknya;

1) Bahwa kemudian pada tanggal 21 Maret 2018 saksi RUDI KHELCES melaporkan terdakwa dengan membuat surat pengaduan ke Polda Sumbar atas==dugaan penghinaan dan pencemaran nama baik melalui What'sApp Group (WAG) dari Asosiasi Kapal Selancar Sumatera Barat (AKSSB);

m) Bahwa adapun pembicaraan yang di permasalahkan saksi RUDI KHELCES yang ada di di WAG AKSSB yaitu pembicaraan pada tanggal 12, 13, 15 dan 28 Januari 2018.

n) Bahwa saksi Lyrianti Dakhi pernah melaporkan saksi Rudi Khelces ke Polda Sumbar karena dugaan tindak pidana penipuan pada tanggal 1 April 2019;

\section{Putusan Nomor 356/Pid.Sus/2020/PN.Pdg}

\section{a. Pertimbangan Yuridis}

a) Berdasarkan dakwaan jaksa penuntut umum dalam kasus ini maka terdakwa dihadapkan ke persidangan dengan dakwaan tunggal yaitu dalam surat dakwaan ini hanya satu tindak pidana saja yang didakwakan, karena tidak terdapat kemungkinan untuk mengajukan alternatif atau dakwaan pengganti yang lainnya. Pada perkara ini terdakwa diancam dengan=pidana dalam Pasal 45 ayat (3) Juncto Pasal 27 ayat (3) UU ITE Perubahan

b) Berdasarkan keterangan terdakwa

c) Berdasarkan keterangan saksi

Untuk membuktikan dakwaan Penuntut Umum menghadirkan saksi-saksi yang terdiri atas nama Rosmawi, S.H, Raihani, Ilham Sastrawan. Atas keterangan saksi tersebut, terdakwa membenarkan dan tidak membantah.

\section{b. Pertimbangan Non Yuridis}

Pertimbangan non yuridis meliputi :

a) Pertimbangan berdasarkan hal yang memberatkan terdakwa :

(1) Perbuatan terdakwa telah menimbulkan rasa malu kepada saksi Rosmawi dan isterinya bernama Raihani;

(2) Terdakwa sudah berulang kali melakukan tindak pidana (Recidivis).

b) Pertimbangan berdasarkan hal yang meringankan terdakwa :

Terdakwa berlaku sopan selama di persidangan

Putusan Terhadap Terdakwa Tindak Pidana Penghinaan Berdasarkan Undang-Undang Informasi Dan Transaksi Elektronik Pada Putusan Nomor 218/Pid.Sus/2020/Pn.Pdg Dan Putusan Nomor 356/Pid.Sus/2020/Pn.Pdg

\section{Putusan Nomor 218/Pid.Sus/2020/PN/Pdg}

Pada tuntutan Jaksa Penuntut Umum dalam putusan Nomor 218/Pid.Sus/2020/PN/Pdg adalah sebagai berikut : 
(1) Menyatakan Terdakwa H. ZAINUL RAHIM ZEIN, S.H. Pgl. AIM ZEIN terbukti secara sah dan meyakinkan bersalah melakukan tindak pidana dengan sengaja dan tanpa hak mendistribusikan, mentransmisikan dan/atau dapat diaksesnya informasi dan/atau dokumen elektronik yang memiliki muatan penghinaan dan/atau pencemaran nama baik sebagaimana diatur dan diancam pidana menurut Pasal 45 ayat (3) Juncto Pasal 27 ayat (3) UU ITE Perubahan dalam Dakwaan Kesatu;

(2) Menjatuhkan pidana terhadap terdakwa berupa pidana denda sebanyak Rp.10.000.000,(sepuluh juta rupiah) subsidair--4 (empat) bulan kurungan.

(3) Menyatakan barang bukti berupa :

a) 1 (satu) rangkap Print out screenshot chat What'sApp AKSSB

b) 1 (satu) buah Flashdisk merek Toshiba $8 \mathrm{~Gb}$ warna putih yang berisikan dokumen elektronik berupa screenshot chat What'sApp AKSSB;

c) Copy Peraturan organisasi AKSSB;

d) Copy Akta Notaris Zurriati Zulherman No. 02 tanggal 14 Januari 2008 dan No. 03 tanggal 23 September 2008 tentang AKSSB.

Berdasarkan tuntutan dari jaksa penuntut umum tersebut. Hakim Pengadilan Negeri Padang berdasarkan fakta hukum yang terungkap dalam persidangan yang dijadikan sebagai dasar oleh hakim dalam memberikan pertimbangan-pertimbangan hukum dan untuk memperjelas maka diuraikan unsur-unsur yang terdapat dalam dakwaan Penuntut umum sebagai berikut :

Menurut Pasal 45 ayat (3) juncto Pasal 27 ayat (3) UU ITE Perubahan memiliki unsurunsur yang meliputi :

Unsur "setiap orang" pada dakwaan kesatu adalah siapa saja yang dapat dijadikan sebagai subjek hukum sebagai pendukung hak dan kewajiban yang dapat mempertanggungjawabkan perbuatannya yang mana dalam perkara ini terdakwa sebagi pelaku tindak pidana sebagaimana identitas terdakwa dalam surat dakwaan dan sepanjang pemeriksaan dipersidangan benar terdakwalah dengan identitas sebagaimana dalam surat dakwaan yang diajukan dimuka persidangan sebagai pelaku tindak pidana, dan hal ini juga telah dibenarkan oleh saksi-saksi dan terdakwa sendiri.

Unsur "mendistribusikan dan/atau mentransmisikan dan/atau membuat dapat diaksesnya informasi dan/atau dokumen elektronik yang memiliki muatan penghinaan dan pencemaran nama baik" menurut Majelis Hakim yang "mendistribusikan" dan/atau "mentransmisikan" dan/atau "membuat dapat diakses" Informasi Elektronik dan/atau Dokumen Elektronik tentang adanya pemberitaan yang menjelek-jelekan saksi Rudi Khelces di WAG AKSSB sehingga menyebabkan Informasi Elektronik dan/atau Dokumen Elektronik dapat diketahui pihak lain atau publik yaitu orang di luar anggota WAG AKSSB adalah saksi Edi Solihin dan saksi Hariyo Seto oleh karena tujuan WAG AKSSB dibentuk adalah untuk kalangan dari WAG AKSSB itu sendiri dan tidak ditujukan untuk bukan anggota WAG AKSSB. Yang mana pembicaraan Terdakwa dengan anggota WAG AKSSB adalah bersifat tertutup yaitu diantara para anggota grup WA itu sendiri yangmana dalam perkara ini adalah membicarakan 
pengalaman para anggota WAG AKSSB tersebut yang tidak menyenangkan sewaktu berhubungan dengan saksi Rudi Khelces, akan tetapi ternyata kenyataannya Informasi'Elektronik dan/atau Dokumen Elektronik tersebut oleh saksi Edi Solihin baik disengaja ataupun tidak ternyata saksi Edi Solihin telah memberikan HPnya kepada saksi Hariyo Seto yang mempunyai kepentingan tersendiri terhadap Informasi Elektronik dan/atau Dokumen Elektronik yang ada di WAG AKSSB tersebut sehingga akhirnya informasi elektronik yang ada di WAG AKSSB tersebut dapat diketahui oleh saksi Hariyo Seto dan saksi Rudi Khelces yang bukan merupakan anggota dari WAG AKSSB dan Terdakwa juga tidak ada "mendistribusikan" dan/atau "mentransmisikan" dan/atau "membuat dapat diakses" Informasi Elektronik dan/atau Dokumen Elektronik tentang adanya pemberitaan yang menjelek-jelekan saksi Rudi Khelces tersebut kepada media sosial lainnya yang bersifat terbuka maupun kepada grup WA lainnya.

Dakwaan kesatu telah dinyatakan tidak terbukti maka majelis hakim akan mempertimbangkan dakwaan kedua yaitu Pasal 310 KUHP.

Perbuatan melanggar ketentuan sebagaimana diatur dalam Pasal 310 ayat (2) KUHP yang memiliki unsur-unsur :

Unsur "barang siapa" dipersidangan Penuntut Umum telah mengajukan H. ZAINUL RAHIM ZEIN, S.H. Pgl. AIM ZEIN, sebagai Terdakwa yang setelah diperiksa identitasnya ternyata identitas Terdakwa tersebut sesuai dengan identitas dalam surat dakwaan dan saksi-saksi yang diajukan dipersidangan menerangkan kenal dengan Terdakwa dan selama persidangan Terdakwa mampu menjawab semua pertanyaan yang diajukan kepadanya, oleh karenanya tidak terdapat error in persona terhadap diri Terdakwa dan Terdakwa adalah orang yang cakap dimata hukum. Unsur barang siapa pada Pasal ini terpenuhi secara sah menurut hukum.

Unsur "dengan tulisan atau gambar yang disiarkan, menyerang kehormatan atau nama baik seseorang dengan menuduhkan sesuatu hal" bahwa sebagaimana telah dipertimbangkan di dalam mempertimbangkan unsur kedua dari dakwaan alternatif Kesatu dimana di dalam WAG AKSSB Terdakwa di dalam menulis informasi melalui media elktronik dengan anggota WAG AKSSB lainnya telah menuliskan kalimat atau kata-kata .

Unsur "yang dimaksud terang supaya hal itu diketahui umum", bahwa tulisan yang dilakukan terdakwa tersebut dilakukan terdakwa dalam WAG AKSSB yang sifatnya tertutup yaitu diperuntukkan untuk para anggota dari AKSSB tersebut yang mana kemudian tulisan Terdakwa di dalam WAG AKSSB tersebut sampai diketahui oleh umum yaitu orang diluar dari WAG AKSSB yaitu diketahui oleh saksi Hariyo Seto dan Rudi Khelces bukan dikarena perbuatan dari Terdakwa melainkan perbuatan dari saksi Edi Solihin yang meminjamkan HPnya kepada saksi Hariyo Seto yang kemudian saksi Hariyo Seto memberitahukannya kepada saksi Rudi Khelces. Sehingga menurut Majelis Hakim unsur ini tidak terbukti; Menimbang, bahwa oleh karena salah satu unsur dari Pasal 310 ayat (2) KUHP tidak terpenuhi, maka Terdakwa haruslah dinyatakan tidak terbukti secara sah dan meyakinkan melakukan tindak pidana sebagaimana didakwakan dalam dakwaan alternatif kedua sehingga Terdakwa haruslah dibebaskan dari dakwaan tersebut. 
Dakwaan alternatif kedua tidak terbukti, Majelis Hakim mempertimbangkan dakwaan alternatif ketiga yaitu Pasal 311 ayat (1) KUHP yang mana untuk membuktikan unsur-unsur dari pasal ini maka juga masuk di dalamnya unsur-unsur dari Pasal 310 KUHP, yang mana unsurunsur adalah sebagai berikut:

Unsur barang siapa, bahwa dengan mengambil alih unsur Barang Siapa dalam pembuktian dakwaan alternatif kedua maka unsur ini juga telah terbukti;

Unsur menista orang lain baik dengan lisan atau dengan tulissan supaya diketahui umum, bahwa unsur ini adalah sama sebagaimana dalam pembuktian dakwaan alternatif kedua Pasal 310 ayat (2) yangmana ternyata Pasal 310 ayat (2) KUHP tersebut tidak terbukti sehingga dengan demikian unsur ini juga tidak terbukti.

Berdasarkan unsur-unsur diatas maka hakim memperoleh putusan yaitu:

MENGADILI:

(1) Menyatakan Terdakwa H. ZAINUL RAHIM ZEIN,S.H Pgl. AIM ZEIN Tidak terbukti secara sah dan meyakinkan menurut hukum bersalah melakukan Tindak Pidana sebagaimana dalam Dakwaan alternatif Kesatu, yaitu: "Dengan sengaja dan tanpa hak mendistribusikan dan/atau mentransmisikan dan/atau membuat dapat diaksesnya Informasi Elektronik dan/atau Dokumen Elektronik yang memiliki muatan penghinaan dan atau pencemaran nama baik" atau dakwaan alternatif Kedua yaitu: melakukan tindak pidana "Menista dengan Tulisan" atau dakwaan alternatif Ketiga yaitu melakukan Tindak pidana "Memfitnah";

(2) Membebaskan Terdakwa oleh karena itu dari semua Dakwaan tersebut (Vrijsfraak);

(3) Memulihkan Hak Terdakwa dalam Kemampuan, Kedudukan, Harkat dan Martabatnya;

(4) Menetapkan Barang bukti berupa:

a) 1 (satu) rangkap Print out screenshot chat What'sApp AKSSB

b) 1 (satu) buah Flashdisk merek Toshiba $8 \mathrm{~Gb}$ warna putih yang berisikan dokumen elektronik berupa screenshot chat What'sApp AKSSB;

c) Copy Peraturan organisasi AKSSB;

d) Copy Akta Notaris Zurriati Zulherman No. 02 tanggal 14 Januari 2008 dan No. 03 tanggal 23 September 2008 tentang AKSSB.

Tetap terlampir dalam berkas perkara.

1 (satu) buah Hp merek Samsung S8 dan simcard nomor 0811669988.

Dikembalikan kepada H. Zainul Rahim Zein,S.H. Pgl. Aim Zein

5. Membebankan biaya perkara ini kepada Negara

Pada putusan ini hakim tidak memiliki pendapat yang sama dengan tuntutan dari jaksa penuntut umum yang dengan dengan jelas disebutkan dalam tuntutan bahwa penuntut umum menjatuhkan pidana terhadap terdakwa sedangkan dalam putusannya hakim membebaskan terdakwa.

\section{Putusan Nomor 356/Pid.Sus/2020/PN.Pdg}

Pada Putusan Nomor 365/Pid.Sus/2020/PN.Pdg memiliki putusan yang berbeda. Dalam putusan ini jaksa penuntut umum mengajukan tuntutan sebagai berikut : 
(1)Menyatakan terdakwa Gonzales Pgl. Igon Bin Charles terbukti bersalah melakukan tindak pidana "dengan sengaja dan tanpa hak mendistribusikan dan/atau mentransmisikan dan/atau membuat dapat diaksesnya Informasi Elektronik dan/atau Dokumen Elektronik yang memiliki muatan penghinaan dan/atau pencemaran nama baik." Sebagaimana dakwaan Pasal 45 ayat (3) Jo Pasal 27 ayat (3) Undang- Undang R.I Nomor 19 Tahun 2016 tentang Perubahan Atas UndangUndang Nomor 11 Tahun 2008 Tentang Informasi dan Transaksi Elektronik.

(2)Menjatuhkan pidana terhadap terdakwa GONZALES Pgl. IGON Bin CHARLES dengan pidana penjara selama 1 (satu) tahun.

(3)Membebani terdakwa GONZALES Pgl. IGON Bin CHARLES untuk membayar biaya perkara sebesar Rp.2.000,- (Dua Ribu Rupiah).

Berdasarkan tuntutan dari jaksa penuntut umum tersebut. Hakim Pengadilan Negeri Padang berdasarkan fakta hukum yang terungkap dalam persidangan yang dijadikan sebagai dasar oleh hakim dalam memberikan pertimbangan-pertimbangan hukum dengan unsur dakwaan sebagai berikut:

Pada perkara ini terdakwa diancam dengan pidana dalam Pasal 45 ayat (3) Juncto Pasal 27 ayat (3) UU ITE Perubahan yang memiliki unsur :

Unsur setiap orang, bahwa berdasarkan identitas terdakwa dapat disimpulkan terdakwa ialah manusia dan unsur setiap orang terbukti.

Unsur dengan sengaja dan tanpa hak mendistribusikan dan/atau mentransmisikan dan/atau membuat ddapat diaksesnya Informasi Elektronik dan/atau Dokumen Elektronik yang memiliki muatan penghinaan dan/atau pencemaran nama baik, bahwa unsur tersebut di atas seluruhnya merupakan unsur tindak pidana yang bersifat alternatif atau kumulatif, sehingga apabila salah satu unsur saja telah terbukti maka sudah dapat membuktikan seluruh unsur tindak pidana lainnya dan bahwa yang dimaksud dengan sengaja menurut M.v.T (Memorie van Toelichting) adalah "kesengajaan" (opzet) dalam arti : "menghendaki dan mengetahui" (wilens en wetens). Si Pelaku harus menghendaki dan mengetahui apa akibat dari perbuatan yang dilakukannya

Berdasarkan unsur-unsur diatas maka hakim memperoleh putusan yaitu:

MENGADILI:

(1) Menyatakan Terdakwa Gonzales Pgl. Igon Bin Charles tersebut diatas, terbukti secara'sah dan meyakinkan bersalah melakukan tindak pidana "dengan sengaja dan tanpa hak mendistribusikan Informasi Elektronik dan Dokumen Elektronik yang memiliki muatan penghinaan dan pencemaran nama baik sebagaimana dakwaan tunggal.

(2) Menjatuhkan pidana kepada Terdakwa oleh karena itu dengan pidana penjara selama 8 (delapan) bulan;

(3) Membebankan kepada Terdakwa untuk membayar biaya perkara sejumlah Rp2.000,00 (dua ribu rupiah); 


\section{KESIMPULAN}

1. Pertimbangan hakim dalam menjatuhkan putusan terhadap terdakwa tindak pidana penghinaan berdasarkan undang-undang informasi dan transaksi elektronik pada Putusan' 'Nomor 218/Pid.Sus/2020/PN.Pdg berdasarkan pertimbangan yuridis yaitu pada surat dakwaan adanya unsur dalam Pasal yang didakwakan tidak terpenuhi, keterangan terdakwa dan keterangan saksi selama di persidangan sehingga hakim menjatuhkan putusan bebas. Pertimbangan non yuridis yaitu dalam putusan ini tidak ditemukan hal yang memberatkan dan meringankan]]terdakwa karena putusan bebas dalam perkara ini. Putusan Nomor 356/Pid.Sus/2020/PN.Pdg berdasarkan pertimbangan yuridis yaitu dalam surat dakwaan yang merupakan dakwaan tunggal dan setiap unsur dalam Pasal yang di dakwakan terpenuhi, keterangan terdakwa dan keterangan saksi di persidangan sehingga hakim menjatuhkan putusan pemidanaan. Pertimbangan non yuridis yakni hal yang memberatkan yaitu menimbulkan rasa malu dan terdakwa merupakan residivis dan hal yang meringankan yaitu terdakwa berlaku sopan selama persidangan.

2. Putusan terhadap terdakwa tindak pidana penghinaan berdasarkan Undang-Undang Informasi dan Transaksi Elektronik pada Putusan Nomor 218/Pid.Sus/2020/PN.Pdg adalah berdasarkan unsur yang tidak terbukti pada Pasal 45 ayat (3) Juncto Pasal 27 ayat 3) pada unsur kedua serta unsur pada dakwaan kedua dan ketiga dan diputus bebas. Sedangkan Putusan Nomor 356/Pid.Sus/2020/PN.Pdg adalah berdasarkan unsur yang terbukti pada dakwaan jaksa penuntut umum dan dijatuhkan pidana penjara 8 bulan.

\section{DAFTAR PUSTAKA}

Danrivanto Budhijanto, Revolusi Cyber Law Indonesia, Refika Aditama, Jakarta, 2017

Fahmiron, Pertimbangan Hakim Dalam Perampasan Aset Koruptor (Dalam Perspektif Perlindungan Hak Anak), Rajawali Pers, Depok, 2017

Mardani, Bunga Rampai Hukum Aktual, Ghalia Indonesia, Jakarta, 2009

Siswanto Sunarso, Hukum Informasi dan Transaksi Elektronik, Rineka Cipta, Jakarta, 2009

Undang-Undang Dasar Negara Republik Indonesia Tahun 1945.

Undang-Undang Nomor 1 Tahun 1946 tentang Peraturan Hukum Pidana(KUHP)

Undang-Undang Nomor 8 Tahun 1981 tentang Hukum Acara Pidana (KUHAP).

Undang-Undang Nomor 3 Tahun 2009 tentang Mahkamah Agung.

Undang-Undang Nomor 11 Tahun 2008 tentang Informasi dan Transaksi Elektronik.

Undang-Undang Nomor 19 Tahun 2016 tentang Perubahan Atas Undang-Undang Nomor 11 Tahun 2008 tentang Informasi dan Transaksi Elektronik.

Undang-Undang Nomor 2 Tahun 1986 tentang Peradilan Umum

Undang-Undang Nomor 8 Tahun 2004 tentang Perubahan Atas Undang-Undang Nomor 2 Tahun 1986 tentang Peradilan Umum. 
Undang-Undang Nomor 49 Tahun 2009 tentang Perubahan Kedua Atas Undang-Undang Nomor 2 Tahun 1986 tentang Peradilan Umum.

Undang-Undang Nomor 48 Tahun 2009 tentang Kekuasaan Kehakiman.

Undang-Undang Nomor 2 Tahun 2002 tentang Kepolisian Republik Indonesia.

Undang-Undang Nomor 16 Tahun 2004 tentang Kejaksaan Republik Indonesia.

Peraturan Pemerintah Nomor 71 Tahun 2019 tentang Penyelenggaraan Sistem Transaksi Elektronik.

Putusan Nomor 218/Pid.Sus/2020/Pn.Pdg.

Putusan Nomor 356/Pid.Sus/2020/Pn.Pdg.

http;//www.romelteamedia.com/media sosial pengertian” dan karateristik, 2018. Html 